УДК 342.365:342.156:342.514

DOI https://doi.org/10.32837/yuv.v0i1.2077

\author{
В. Мельник, \\ кандидат политических наук, \\ ассистент кафедры политологии \\ Киевского национального университета имени Тараса Шевченко, \\ преподаватель кафедры философии и общественных наук \\ Винницкого национального медицинского университета имени Н. И. Пирогова, \\ главный редактор журнала «Анналы юридической истории», \\ член Американского общества юридической истории

\section{ПЕРИОД «ПЯТИЛЕТНЕЙ НЕСТАБИЛЬНОСТИ» (579-584 гг.): ПОЛИТИКО-ПРАВОВЫЕ ОСОБЕННОСТИ ИРАНО-ВИЗАНТИЙСКИХ И ВИЗАНТИЙСКО-ТЮРКСКИХ ВЗАИМООТНОШЕНИЙ}

Термин «пятилетняя нестабильность» мы предлагаем использовать для обозначения предкризисного времени, наступившего в мировой политике во второй половине VI века ${ }^{1}$. После смерти главных идеологических оппонентов поздней античности (византийского императора Юстиниана Великого и персидского шахиншаха Хосрова Ануширвана) все политические системы Старого Света стремительно разваливались. Этому особенно помогала ирано-византийская война 572-591 годов [2, с. 91-123]: на сирийском, месопотамском и закавказском фронтах к началу 579 года решались судьбы Восточной Римской империи (Византии) и Новоперсидского царства (Эраншахра).

Цели данной статьи - обосновать термин «пятилетняя нестабильность» в хронологических рамках 579-584 гг., а также продемонстриро-

${ }^{1}$ Мы говорим именно о «предкризисе», так как «настоящие» проблемы будут ждать восточноримскую и персидскую государственности только в начале VII века. В 602 году начнется «Мировая война», которая закончится в 650-х гг. созданием Арабского Халифата и полным разгромом Ирана и Византии арабскими кочевниками [1]. Однако, понять корни этой «Мировой войны» можно только зная факты и политико-правовые особенности развития Евразии в конце VI века. вать пути развития международной правосубъектности на фоне ирано-византийско-тюркских взаимоотношений. Основной правоведческий интерес составляют процессы смены верховной государственной власти Византии, Эраншахра и Тюркского каганата. В 579 г. трон шахиншаха Персии получил Ормизд IV, в 581 г. Гёктюрк-каганом стал Бага-Ышбар, а в 582 г. императорскую диадему Византии одел генерал Маврикий. Соответственно, главная точка отсчета характеризуемого нами периода - смерть персидского шахиншаха («царя царей») Хосрова Ануширвана, случившаяся 31 января 579 года.

Преемник Ануширвана Ормизд IV Тюркзаде был наполовину тюрком, наполовину персом. Его отец Хосров Ануширван являлся персидским шахиншахом, в то время как мать была дочкой западнотюркского ябгу Истеми-кагана [3, с. 466-469]. Вот почему новый шахиншах Эраншахра с 579 г. носил прозвище «Тюркзаде» (Тюркский сыьн, сын тюрчанки) [4, с. 245].

Официальная интронизация Ормизда Тюркзаде на сасанидский престол состоялась 1 июля 579 г. и прошла в торжественном зале 
церемоний Ктесифонского дворца. На ней присутствовали как зороастрийские мобеды, так и ктесифонский несторианский патриарх Мар Эзекбиэль (566-581) [5, pp. 407-422]. Также на коронацию прибыли отдельные тюркские легаты, посольства индусов и китайцев. Не было только официальных представителей Восточной Римской империи. Его современники, византийские хронисты Иоанн

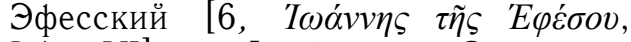
Lib. VI] и Феофилакт Симокатта [7, Theophylactus Simocatta. Historia. Lib. III] в один голос ругают Ормизда Тюркзаде за то, что он даже не послал официального посольства в Константинополь с уведомлением о своём вступлении на трон, несмотря на то, что император Тиберий (578-582) к тому времени вёл активные переговоры о прекращении боевых действий с легатами умершего Хосрова Ануширвана (531-579).

Иоанн Эфесский написал: «Когда умер царь Хосров, после него воцарился один из его сыновей по имени Хормизд, который был юноша страстный, грубый, малосообразительный, как об этом говорят его бесстыдные выходки и поясняют сами его дела. Когда он воцарился, он был так горд и неумен, так высокомерен и нахален, что даже не послал римскому императору, по царскому обычаю, символа царствования. Этот же неумный царь гордо говорил: «Для чего я буду посылать подарки моим рабам?»

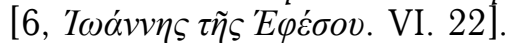

Уже через несколько дней после коронации персидские переговорщики были отозваны Ормиздом Тюркзаде (579-590) в Ктесифон и получили выговор за попытку примирения с «исконным врагом персов» [2, с. 100]. Ормизд провозгласил римлян «вечными врагами персидской культуры» и объявил всеобщую мобилизацию персидских военнослужащих. Впрочем, император Тиберий решил действовать на опережение и отправил войско своего генерала Маврикия для интервенции в Перс-Армению. Необходимо подчеркнуть, что пятидесятитысячный корпус генерала Маврикия действовал крайне быстро и галопом проскакал Перс-Армению, Атропатену, привлекая попутно бунтовщиков армянского и албаноазербайджанского происхождения [о роли Атропатены в происходящих процессах: 8, с. 37]. С севера корпус Маврикия, усиленный армянскими ополченцами, вторгся собственно в Мидию, где осуществил тотальную резню зороастрийских священников, уничтожил местные посевы, разграбил продовольственные склады. Bсе добро караванами отправлялось в византийскую Армению и Месопотамию, а Мидия вплоть до конца 579 2. оставалась под контролем генерала Маврикия [7, Theophyl. Hist. Lib. III. 17. 4].

Персона Маврикия, женатого впоследствии на дочери Тиберия (578-582), занимает центральное место в истории временного расширения пределов Восточной Римской uмперии 579 г. Армейские подразделения, с одной стороны, грабили и убивали персо-мидян, но, с другой стороны, они впервые предпринимали также административно-правовые шаги, направленные на укрепление своей непосредственной политической власти в сердце Сасанидского Ирана. В этом контексте, политический талант и, скорее, удача Тиберия (578-582) [9, с. 307], бывшего генерала юстиниановых войск, намного превзошла сошедшего с ума Юстина II (565-578) [10, с. 31-33].

Тиберий планомерно работал с различными социально-политическими группами. Его интересовало примирение монофизитов и ортодоксов в Христианской Церкви. Он жаждал устранения противоречий в судебной юрисдикции между ортодоксальными патриархатами Рима, Константинополя и Александрии. Тиберий постоянно жертвовал огромные деньги на возврат антиохийцев к нормальной 
жизни, нарушенной неоднократными вторжениями Хосрова Ануширвана (531-579). Также Тиберий рассматривал восточные провинции Римской империи как основу её политико-правовой мощи. Именно Сирию, Армению и Египет в своих законодательных актах Тиберий призывал считать оплотом «ромейства» в Азии. Понимая и воспринимая азиатский вектор юстиниановой внешней политики, Тиберий (578-582) считал любые дела, связанные с вторжением лангобардов в Италию или вестготов в Испанию, маловажными. Все конфликты с восставшими варварами-федератами вдоль границ юстиниановой реконкисты, Тиберий думал устранить в случае окончательной военной победы над Ормиздом Тюркзаде. Тиберию соприятствовала оккупация его зятем Маврикием исконно персидской Мидии, а также крайне плохое отношение персидских чиновников эпохи Хосрова к шахиншаху Ормизду.

Что же не устраивало персидскую знать?

Как мы указывали ранее, Хосров Ануширван написал своё имя в истории золотыми буквами в тот момент, когда усыновил тысячи брошенных детей, изъял их из тяжелого маздакитского рабства, предоставил каждому приданное, должность или стартовый капитал [11, с. 188]. Кроме того, Хосров Ануширван пожизненно содержал их и предоставлял самые ответственные должности. Учитывая особенности персидского менталитета, случаи предательства среди них по отношению к Ануширвану являлись единичными. Однако, в тот момент, когда Хосров Ануширван, утверждая мирный договор с Тюркским Элем (565 г.), взял в жены родную дочь ябгу Истеми, среди персидской знати начался ропот и волнения, связанные с игнорированием Ануширваном детей от персидских царевен [3, с. 468]. Согласно нотариально заверенному завещанию Хосрова
Ануширвана [3, с. 468], вся полнота власти над Эраншахром, немедленно после его смерти, без обсуждения но военном совете, и вопреки наличию огромного количества детей, как родных, так и усыновленных, имевших исключительно сасанидское происхождение, должна была перейти к «Тюркзаде» - ребенку тюрчанки, отпрыску «Турана», враждебного авестийскому «Ирану» [12, рр. 3-33].

В 565-567 гг. отношения между тюрками и персами складывались еще сравнительно неплохо. Однако край дружбе положил сам Хосров Ануширван, когда испугался возрастающего значения тюрок в Согдиане [3, с. 590-592]. До 565 г., несмотря на эфталитские грабежи, основная масса денег и драгоценностей, а также десятина товара по таможенному сбору, уходили в казну Сасанидского Эраншахра. То есть основным выгодополучателем Великого Шелкового Пути, основанного северными китайцами, являлись именно персы. Путь купеческих караванов и шелковые грузы перемещались почти исключительно через земли Эраншахра [13, с. 542]. Так было и при династии Парфян, и при династии Сасанидов. Однако, упрочение позиций Восточной Римской империи Юстинианом Великим в 527-565 гг., создание Великого Тюркского Эля в 545-553 гг., установление одновременно дружеских дипломатических отношений Муган-каганом (553-572) с китайскими и восточноримскими императорами, в корне поменяли ситуацию. Тюркский каганат занял огромную территорию - от Владивостока и Северной Кореи до Волги (в 565 г.), а позже сумел даже выйти к Днепро-Бугскому лиману в районе древнегреческой Ольвии (567-578 г2.). Случилось невозможное - Персию торговиам теперь вообще можно было обходить. В 563-565 гг. Юстиниан Великий сумел получить секрет шелкопрядения, в обход персидской экономической конъюнктуры, 


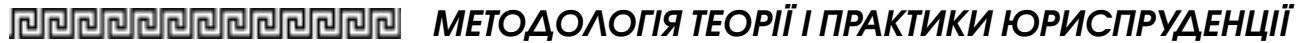

установив через тюрок непосредственные контакты с северными китайцами [14, pp. 64 - 653; 15, c. 187]. Торговля контролировалась грекоязычными несторианами Мерва, Хорезма и Согдианы [16, с. 11]. Они, сами того не желая, принесли византийскую культуру в ставку Муган-кагана на Алтае и цивилизационно византинизировали монгольскую степь [17, с. 46-51]. В свою очередь, тюрки из династии Ашина активно перестраивали политическую карту Восточной Европы и регулярно посылали посольства в Новый Рим. Сасанидский Иран переставал играть роль Срединного государства. Теперь он был просто частью Ойкумены, которую караваны спокойно могли обойти. Путь купцьов менялся. Если до 565 г. они, опасаясь әфталитов и любых других диких кочевников, обходили Каспийское море с юга, а также платили больuие dеньги шахиншаху за сопровождение товаров через потенциально эфталитские горные долинь Афганистана, Таджикистана, Узбекистана, то после 566 г. купцьь любого подданства могли спокойно идти через казахстанскую степь под конвоем тюркских всадников, обходить Каспийское море с севера u, в итоге, nonaдать в Восточную Eвропу, где получали от тюрок, остготов, антов неплохой «бонусныц̆» товар в виде рабов.

Экономически, китайцам и согдийцам стало выгоднее использовать маршрут через Казахстан, Поволжье, Дон и, либо останавливаться в Крыму, либо двигаться вдоль черноморского берега до Мезии, Фракии и даже Нового Рима. Благодаря такой расстановке сил и, несмотря на свирепые вспышки бубонной чумы, терроризировавшие Евразию с 540 г., под конец правления Юстиниана Великого, в 565 2. Константинополь сумел обрести статус не только столиць всего Христианского Мира, но и стать новым рынком сбыта для китайских, согдийско-хорез- мийских и тюркских купиов. Вот почему, при Юстине II, в 567-568 гг. ябгу Истеми-каган, без каких либо колебаний, принял условия договора о предоставлении императором lex foedus [см. нашу интерпретацию: 18, с. 139-155]. Финансовоэкономические выгоды федератских (то есть, подчиненных) отношений западнотюркской орды с Новым Римом были намного выгоднее правосубъектного равноправия. В этом смысле, тюркам всегда хватало мудрости намного больше, чем многим ираноязычным и даже славянским племенам, соседствовавшим с ними на громадных просторах Восточноевропейской равнины. Тюрки были хитры, сдержанны, немногословны, религиозно не экзальтированны, толерантны к чужим культурам, но не толерантны к предательству и негостеприимству [19]. Именно поэтому они были чрезвычайно опасны для морально неустойчивых варваров-федератов Восточной Европы.

Хосров Ануширван (531-579) испугался мощи этой тюркской цивилизации. Он боялся «наивной правды» тенгрианства [17, с. 299-324]. По примеру своих старых ахеменидских предков, он понимал, что земледельческие культуры Средней Азии (в частности, древнее Мидийское царство и Вавилон завоеванные в 550-х гг. до н. э. Киром Ахеменидом), циклично и регулярно завоевывались горными скотоводами-кочевниками. Разгром эфталитов и войны с Юстинианом забрали у Хосрова слишком много военно-политической энергии. Компенсировать её было неоткуда. Вот почему первое боестолкновение Ануширвана с Муган-каганом в 568-571 гг. окончилось миром и выплатой подарков на Алтай из Ктесифона. Граница установилась вдоль великой реки Амударьи. Средняя Азия впервые оказалась разделенной между персами и тюрками. Опозоренный и отнесенный к веданию Аримана в кодифицированных 


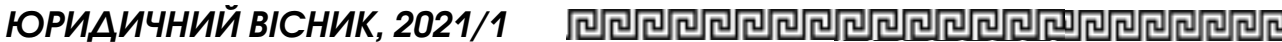

Ануширваном Авестах «Туранский народ» [20, с. 85-89] оказался сильнее и смышленнее «Иранского народа». Фактически, ираноязычные народы Персии, а также попавшие под власть тюрков в 567-568 гг. аланы и сабиры Предкавказья, поняли, что Авесты, выражаясь обыденным языком, «лгут». Никакой победы богоизбранного персидского народа, пленившего когда-то иудеев, поразившего мидян и индусов, уничтожившего белых гуннов-эфталитов, в реальности не существует. Просто одни орды «туранцев» (то есть кочевников, степняков, а также горных скотоводов, исповедовавших не зороастризм-огнепоклонничество, а тенгрианствонебопоклонничество) регулярно сменялись другими ордами, что заставляло все новых и новых сынов Персидской цивилизации гибнуть в нескончаемых войнах.

Великий Тюркский Эль, как символичное воплощение Ариманового турана, начал подрьвать авестийское мировоззрение персомидян Сасанидского Ирана. Само существование Тюркского каганата на столь огромных пространствах, его победы над регулярной персидской армией, высокое образование и мудрость тюркских каганов - все это играло против шахиншахской власти. Народные массы Персии теряли веру в религию предков [19, с. 76]. Когда-то что-то подобное переживал Императорский Рим времен принципата $(27$ г. до н. э. -284 г. н. э.), что, однако, не помешало римлянам обрести душевное успокоение через распространившееся из Палестины христианство. Религия Иисуса Христа спасла Римскую Державу, позволила ей укрепиться при Константине Святом (306-337) и восстановиться в укрупненном масштабе при Юстиниане Великом (527-565) [21]. Монофизитство и несторианство, хоть и являлись деструктивными еретическими сектами, но развивались комплиментарно Римской идее, греко-римской античной цивилизации. Оппозиционируя ортодоксальному христианству пяти патриархатов имперского диптиха, несториане и монофизиты, не желая этого, развивали и распространяли интеллектуальную мощь Византии [22, с. 113-119]. Переселяясь вплоть до Амударьи, Сырдарьи и Алтайской степи [23, с. 76-85], несториане несли с собой ненависть к Константинопольскому патриархату и восточноримским императорам, инициировавшим гонения против них, но также и знание об этих событиях, что было ново и экзотично для степняков Алтая, Монголии и Маньчжурии, традиционно ориентировавшихся до 563-565 гг. только на внутрикитайские политические, культурно-религиозные и социально-экономические процессы. Открыв тюркам Монголии и Алтая новый мир позднеантичной Ойкумены, несториане [16, с. 10-12] и монофизиты постепенно возродили греческий койне там, где он был внедрен еще при Александре Македонском (336-323 гг. до н. э.), совершили новую волну эллинизации территорий современных Афганистана, Таджикистана, Киргизии, Узбекистана и Казахстана [24]. Греческое несторианство проникло в пределы нынешней китайской Сынцзян-Уйгурии, стало нормальным явлением среди степных предков монголов [17, с. 51]. О Византии узнали на озере Байкал, и это знание помогло номадам сделать торговлю вдоль Великого шелкового пути более масштабной. Если ранее номады Монголии чаще выступали угрозой в торговле Персии и Китая, то с момента образования Тюркского Эля степняки заняли позицию защитника этой торговли, ставшей географически намного более широкой и масштабной. Плюс, к этой экономической деятельности подключились согдийцы [14, р. 649], которые заняли привилегированное положение в новой практике администрирования Великого Шелкового пути $[25$, с. $27-35]$. 


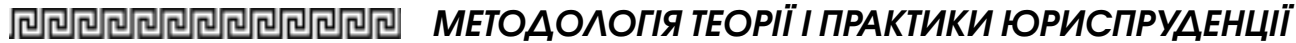

Ормизд Тюркзаде (579-590) потерял значительную часть Мидии в 579 г. [7, Theophyl. Hist. Lib. III. 17. 4], но уже в 580 г. мобилизованное им войско атаковало византийскую Месопотамию [2, с. 100]. К тому времени Тиберий успел выдать свою дочь за Маврикия и провозгласить его «августейшим полководцем» [26, с. 16]. В 582 г. Маврикий стал официальным правопреемником Тиберия на посту императора. Об этом Тиберий объявил Константинопольскому сенату и послал соответствующее извещение Римскому Папству. Несмотря на тяжелые потери византийского дуката в Месопотамии, Маврикию удавалось удерживать Перс-Армению и часть Мидии в своих руках. Там была создана византийская администрация, а порядок поддерживался армянскими и азербайджанскими дружинами. В иастности, несмотря на упомянутую хрониками «войну тюрок с византийцами 576-581 ге.», именно тюркские подразделения активно помогали генералу Маврикию в его каспийско-мидийской операщии ${ }^{2}$. С юга, на Ктесифон усилилось давление гассанидских арабов, угрожавших Ормизду Тюркзаде объединением с византийцами под стенами древнего Вавилона. Операция Ормизда в Месопотамии была, по нашему мнению, направлена именно на то, чтобы разрезать силы Гассанидов и тюрко-византийцев Маврикия.

Упоминая о тюрках, не станем

2 Этот факт лишний раз подтверждает существование режима lex foedus в отношениях Восточной Римской империи с частью западнотюркской орды (видимо, речь надо вести о клане ябгу Истеми).

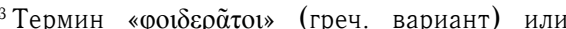
«foederati» (лат. вариант) после смерти Юстиниана Великого использовался хронистами редко, но почти все они говорят о «союзах» или «союзных племенах». Прокопий Кесарийский указывает, что кочевники Северного Причерноморья были «подвластными» Восточной Римской империи [29, Procop. BG. VIII, V, 26; 27; 28]. Причерноморские готы, согласно Прокопию, были восточноримскими «воинами» [30, Procop. De aedificiis. III, VII, 13]. также забывать того факта, что «война византийцев с тюрками» являлась не менее комплиментарным в культурном контексте феноменом, нежели несторианская христианизация согдианцев, уйгуров и протомонголов Центральной Азии. Во-первых, основание тюрками Тьмутаракани [27, с. 24] шло вразрез с планами эллинизации Приазовья, которые строили византийские стратеги Боспора Киммерийского. Захват Боспора западнотюркской ордой в 576 г. осуществлялся, к тому же, только частью этой орды. Истемикаган не поддержал новую политику Татпар-кагана (572-581) и не подчинился новому ябгу тюркского запада. Торжественные похороны Истеми-кагана стали настоящей демонстрацией дружбы византийцев и западных тюрок. На похороны Истеми прибыло целое посольство от имени императора Юстина и цезаря Тиберия. Когда же Тиберий (578-582) сам стал императором, среди тюрок оставалось огромное количество приверженцев дружбы с Восточной Римской империей [28, Menander 45]. Особенно эта позиция была сильна среди традиционных федератов Константинополя - хазар, аланов, сабиров. Более нейтральную роль играли утригуры, охотно шедшие на контакт с буддистской властью Татпар-кагана (572-581)

Период 572-581 гг. в западнотюркской орде предлагаем характеризовать как «эпоху шатаний и неясности». $100 \%$ всех известных исторической географии племен между Волгой, Кавказом и Днепром, имели lex foedus с Восточной Римской империей еще со времен Юстиниана Великого (527-565)3. Эти договора были подтверждены и Юстином II (565-578). Тиберий (578-582), в свою очередь, подтвердил юридическую силу всех решений своего предшественника Юстина [28, Menander 45]. Он не осуществил никаких кардинальных изменений во внешней политике 
Юстиниана Великого. Таким образом, любое выступление тюрок или утригуров против империи - в Крыму, на Кавказе, близ Днепро-Бугского лимана - все эти действия четко попадали под определение внутригосударственного мятежа или бунта. Оккупация Боспора тюрками в 576 г. [31, с. 67], непослушание огузов и утригуров ябгу Истеми-кагану - все это были преступления ${ }^{4}$, которые Тиберий обязан был пресечь.

Для антитюркской операции в Восточной Европе Тиберий подготовил экспедиционный крымский корпус, а также использовал ополченцев из Армении и Лазского царства. В 579 г. таврический легион византийцев начал оттеснять тюрок от Южного Буга и Днепра, в то время, как армяно-грузинская армия нанесла тюркам ряд поражений в пределах современной Абхазии $[19$, с. 50, 108]. Противостояния также ужесточились на уровнях аланы vs. хазары и утригуры vs. кутригуры. Вновь назревал передел Восточноевропейской степи, в котором первую скрипку, конечно же, играли славянские племена [32, c. 49].

В 578 г., более чем 100-тысячный контингент славян из Поднепровья (в литературе именуемых «антами» $[27$, с. 19]), в союзе с западнотюркской ордой, пересек Дунай и вторгся в восточноримские провинции Мезия и Фракия [28, Menander 50; 33, с. 38]. Эти антские подразделения не имели нормального командования и часто воевали друг с другом, отличаясь особой жестокостью [34]. Как отмечали византийские хронисты, суровость славян превзошла все ожидания восточных римлян, помнивших практику издевательств и массовых казней, предпринятых антами во время похода Заберхана (559 год). Прошло 19 лет. Теперь многие славяне, которые ранее подчинялись булгарам-ку-

${ }^{4} \mathrm{C}$ позиций римского публичного права, конечно же. тригурам, попали в зависимость от стоявших на левобережье Днепра кочевий Тюркского Эля [19, с. 106]. Тюрки обещали славянам богатую добычу, поддержку на втором фронте (Кавказ и Крым) и защиту в случае похода Тиберия в сторону Поднепровья. Многие анты также банально жаждали мести за свой неудачный поход 19-летней давности, приведший к аварскому порабощению.

Основные силы Восточной Римской империи находились на мидийско-персармянском направлении [7, Theophyl. Hist. Lib. III. 17 et 18]. Там шли главные сражения, в которых империя напрягала все силы, чтобы удержать не только выход к Каспийскому морю, но и, чтобы сосредоточить первые ростки римской администрации в собственно Иранском нагорье [7, Theophyl. Hist. Lib. III. 18. 1]. Главный полководец империи Маврикий командовал мидийским фронтом, а также пытался спасти от Ормизда Тюркзаде Месопотамию, не так давно полностью разграбленную Ануширваном.

Таким образом, противостояние Маврикия и Ормизда, открыло западнотюркской орде путь в Грузию [19, с. 108]. Это ударило по византийцам с тыла, но, что еще хуже, поставило под удар весь Балканский полуостров [28, Menander 50]. Стотысячная толпа славян представляла не организованное войско, а именно орду - повозки с домашним скарбом, целые семьи: мужчины, женщины, дети, старики. Племена из Поднепровья двинулись на Балканы, предварительно заключив союз с представителями западнотюркской орды. Растянувшись вдоль дунайской границы, славяне грабили и убивали, повторив для фракийцев горький опыт вторжения Заберхана в 559 г. [32, с. 35]. Однако, теперь славяне также занимались обустройством поселений вдоль Дуная. Это, безусловно, нарушало устоявшуюся после 560 г. торговую систему 


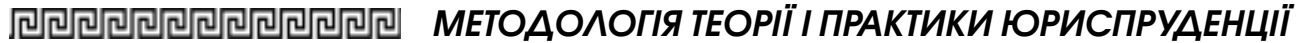

транзита «лесная Европа - Средиземноморье», на страже которой находились остготы [30, Procop. De aedificiis. III, VII, 10-17] (западный берег Черного Моря - от Тираса до Ольвии) и авары [28, Menander 45] (Паннония, Дакия, Трансильванское плато). Переселение славян непосредственно нарушало интересы аварского кагана Баяна I (558-602) и Тиберий (578-582), хоть и с опозданием, обратился к кагану за помощью [28, Menander 50].

Почему Тиберий обратился именно к Баяну? Исключительно потому, что Аварский каганат являлся творением Юстиниана и, к тому же, обладал федератскими обязательствами [18, с. 143]. Баян, соответственно, был дуксом византийских федератов, чиновником на службе империи, личным подданным императора Нового Рима. Учитывая совпадение интересов империи и каганата, Баян действительно мобилизовал большую славяно-аварскую армию и ударил поднепровским сородичам-антам в тыл [28, Menander 50]. Основные сражения этой малоописанной войны (все внимание тогда отдавалось именно успехам генерала Маврикия, угрожавшего уже непосредственно Ктесифону и Вавилону) состоялись у города Сирмия - экономического центра римской Паннонии [35, с. 94]. Часть поднепровских славян, впрочем, сумела силой захватить отдельные центры на севере Эллады

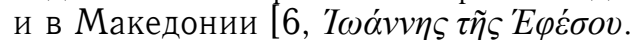
VI, 25]. Здесь Тиберий отдал приказ вести переговоры со славянскими поселениями местным дуксам, которые, видимо достигли соглашения о временном размещении в македонских долинах. Однако, разгром, учиненный славяно-аварами антам на территории Паннонии и Дакии был чрезвычайным [36, s. 83-84]. Можно предположить, что славяно-аварская орда громила антские колонны переселенцев по всему протяжению Карпатских гор - по сторонам гор- ных хребтов. Лидер антов и союзник западных тюрков Даврит погиб в одном из таких боев, а аварское владычество серьезно упрочилось вплоть до низовьев Южного Буга.

В боях 578 г. славянские подразделения участвовали как на стороне аваров, так и на стороне тюрок. Против поднепровских и бужских антов, вторгшихся огромным числом на Балканы, выступили славяне, переселившиеся в 568 г. с аварами на территорию Паннонии - склавины, ближайшие родственники антов. Славян-антов, таким образом, громила именно славяно-аварская орда. Это факт. Но еще интереснее, что на стороне Восточной Римской империи вновь выступали федераты-кутригуры и федераты-остготы. Они обеспечили уничтожение бессарабского фланга антской орды в 578-579 гг. Угроза дальнейшего переселения была локализована, но сотни антских поселений на юго-востоке Балкан остались и к 582 г. все же получили статус федератов. Следовательно, некоторой тактической цели поднепровские славяне этим походом добиться смогли.

Проблема, впрочем, пришла опять со стороны федератов. Пока византийцы, с кутригурами, остготами и хазарами, нанесли ряд поражений сторонникам Татпар-кагана (572-581) на Кубани, а анты потерпели сокрушительный разгром на Балканах от своих славяно-аварских сородичей, Баян I (558-602) решил использовать многовекторное ведение боевых действий Тиберием (578-582) в корыстных изелях. Убив главного союзника тюрок, антского князя Даврита, Баян совершил поворот на 180 градусов и, без каких-либо дипломатических объяснений, взял в осаду важный восточноримский город Сирмий [28, Menander 65-66]. Видимо Баян почувствовал свою власть крепкой как никогда [37, с. 276]. Все славяне Паннонии, Дакии и Бессарабии подчинились ему безоговорочно, последний антский самостоятельный 
князь погиб и аварские кочевые разъезды вернулись к междуречью Южного Буга и Днепра. Западные тюрки стремительно отступали к Волге и, оттесняемые кутригурами и утригурами, получали также удары от аланов и хазар. Это означало, что в западнотюркской орде разгорелась гражданская война, спровоцированная безвластием после смерти Истеми-кагана в 576 г. и поддерживаемая византийцами Крыма. Немалую роль в этом процессе играли также причерноморские остготы [38, с. 300-308].

Итак, Аварский каганат теперь не только формально, но и де-факто вернул под свой контроль Бессарабию и часть современной Правобережной Украины. Баян хотел упрочения своего положения в политической жизни Византии и потребовал увеличения жалования для его ордынцев, а также масштабного увеличения сумм ежегодного подарка со стороны восточноримского императора [7, Theophyl. Hist. Lib. I. 3. 6]. Осада Сирмия длилась с конца 579 г. и до начала 582 г. В 582 году город наконец пал и стал одним из центров славяно-аварской колонизации Балканского полуострова [37].

Подчеркнем: падение Сирмия в 582 г. не было переходом древнеримского центра провинции Паннония в состав нового государства (Аварского каганата). Падение Сирмия изменило только политическую расстановку сил на восточноевропейской шахматной доске [32, с. 50]. С момента захвата Баяном, Сирмий юридически оставался византийским городом. Да и Аварский каганат, де-юре, оставался союзом племен-федератов под руководством Баяна. Однако, как и в случае с остготами 535-552 гг. в Италии, этот Аварский каганат, население которого почти полностью состояло из славян, поднял мятеж, подлежавший усмирению восточноримскими регулярными войсками. Формально, с позиций римского публичного права, сла- вяно-авары были не более чем бунтовщиками, нарушившими закон и выступившими против своего сюзерена - «благодетеля-императора» [39, c. 65-104].

Политически ситуация являлась более сложной и многогранной. Получалось, что славяно-авары не просто предъявили требования об увеличении жалования в золотом эквиваленте, но и впервые захватили город - полноценный полис античного образца, где сохранялись и функционировали религиозные, административные, полицейские институты. Они взяли под контроль латиноязычное население окрестностей и, пользуясь услугами перебежчиков из стана византийских пограничников, предприняли первую попытку славянизации окрестностей Сирмия [40]. Так, кстати, славяне впервые организованно появились на территории современной Сербии. И организаторами этого появления выступили авары. Ставка кагана Баяна хотела увеличения областей, которые она могла грабить и, в дальнейшем, обменивать на определенные выгоды. Пользуясь старыми методами кочевников, Баян решил, что методика Аттилы (434-453) была самой выгодной. Напоминаем, что именно Аттила был правителем, умудрявшимся и дружить, и воевать с римлянами одновременно. По всей видимости, зная опыт жужаней в Китае и гуннов в Римской империи, Баян решил не только его тактически использовать, но и стратегически превзойти. Захват славяно-аварами Сирмия в 582 г. стал первым шагом славянства к колонизации Балкан и к созданию южнославянской группы этносов. Осуществлен он был исключительно благодаря военным умениям номадов. Методика Баяна была очень простой: сражались славянские пехотинцы, командовали аварские кавалеристыл. В этом творческом симбиозе славяно-авары и начали медленную, 


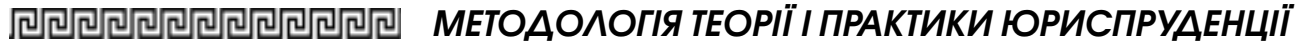

постепенную, но весьма уверенную колонизацию Балкан [33, с. 36-38].

Пока славяно-авары осуществляли Сирмийскую операцию, в 580 г. западнотюркская орда атаковала Лазикское архонтство [19, с. 105]. Маврикию пришлось отвлекать часть регулярной армии от армяно-мидийского фронта для помощи небоеспособным грузинским князьям. По всей видимости, учитывая такой поворот событий в 580 году, мы можем также предположить, что Ормизд Тюркзаде (579-590) сумел наладить отношения с западнотюркским ябгу Жутаньханом. Тогда прошел только один год с момента коронациии Ормизда и старая вражда условных «Ирана» и «Турана» вполне могла временно «сойти на нет» посредством персоны наполовину иранца и наполовину тюрка Ормизда. Персидский шахиншах предложил мир Татпар-кагану (572-581) и, вполне очевидно, сумел связаться с его ставленником в Тьмутаракани - ябгу Жутанем.

Отношения между Жутанем и Ормиздом проследить трудно, поскольку Татпар-каган в конце 581 г. умер после непродолжительной болезни [41, s. 72]. В частности, высказываются предположения, что умер он во время очередной вспышки бубонной чумы. В любом случае, смерть Татпар-кагана стала ударом не только для впервые с 565 г. назревшего союза персов и тюрок, но и сильно била по внутреннему единству самого Тюркского каганата [42, с. 138]. Немедленно после смерти Татпара началось грандиозное противостояние между его сыновьями, боровшимися друг с другом на почве меньшей или большей знатности собственных матерей. Эта война разрывала каганат целый год с 581 по 582 гг. K моменту захвата славяно-аварами Сирмия, на престоле кагана Великого Тюркского Эля сумел утвердиться Бага-Ышбархан (581-587). Его предшественник Амрак (581) правил всего несколько месяцев и запомнился современникам только тем, что не отвечал «достойно» на публичные оскорбления противниками [19, с. 106].

Со своей стороны, позволим себе подчеркнуть: Великий Тюркский Эль к середине 582 г., не без недальновидной внутренней и внешней политики Татпар-кагана (572-581) успел погрязнуть в конфликтах религиозного и дипломатического характеров [19, с. 103]. C религиозной точки зрения, восточнотюркская орда массово переходила в буддизм и предавала древнюю религию тенгрианства. Это вызывало недовольство на Алтае и в Приморском регионе, где отношение к «китайским новшествам» традиционно было нетерпимым. Народы к северу от древней Китайской Стены хорошо помнили практики геноцида и тотального истребления номадов, предпринимаемые отдельными китайскими императорами и царьками еще в хуннскую эпоху.

Бага-Ышбар-хан $\quad$ (581-587) [19, с. 106], в отличие от Амрака (581), был внуком основателя Великого Тюрского Эля Бумын-кагана (545-552) по линии второго Гёктюрк-кагана Кара-Иссык-хана (552-553). Именно Кара-Иссык-хану в 553 г. наследовал Муган-каган (553-572), ставший основным провизантийским властелином Тюркского каганата. Соответственно, линия Бага-Ышбархана (581-587) являлась влиятельной именно среди провизантийски настроенной части монгольско-алтайских кочевников [о провизантийской партии, постепенно вернувшей власть в Тюркском Эле: 9, с. 373].

Что мы подразумеваем под «nровизантийскостью»?

Конечно же, время для тотальной политической, юридической и военной инкорпорации Евразийского Эля тюрок в состав Восточной Римской империи безнадежно ушло. Из-за мягкой и не всегда скрупулёзной политики Тиберия (578-582), которую в первые годы регентства детерминировала жена слабоумного Юстина II 
(565-578) София, Новый Рим утратил шанс способный кардинально изменить мировую политическую карту. Речь именно о реальной возможности ассимилировать степные обычаи ${ }^{5}$, что почувствовал и осознал Юстиниан Великий (527 565). Этот выдающийся деятель мировой политической и юридической истории создал своими распоряжениями и слаженными военными действиями Аварский каганат (558-805) и признал Тюркский Эль «достойной» военно-политической силой. Его сотрудничество с Истеми и Муганом, хотя и не было долгосрочным, но оставило приятный шлейф воспоминаний для тюркских воинов вплоть до неудачной общей кампании против персов (568-573 гг.). Тюрки Муган-кагана были вынуждены заключить мир с Хосровом Ануширваном еще в 571 г., так как византийцы просто-напросто бросили их и не пришли на помощь с запада. Впрочем, тюрки понимали, что племянник Великого Юстиниана Юстин II (565-578) болен и неспособен принимать решения. В 573 г., когда Хосров Ануширван лично сжег крепость Дару на месопотамской границе [6, 'Т

${ }^{5}$ Большую часть дальнейшей номадской истории, обычаи, каноны и традиции степняков будут существовать исключительно в форме устного народного творчества, трансформируясь в зависимости от реалий существования тюрок в треугольнике Восточная Римская империя-Китай-Персия (речь идет даже о временах, когда Персия стала мусульманской после 632-655 гг.). Первую и полную систематизацию этих норм, санкций и табу осуществит славный багадур Тэмуджин, принявший в 1206 г. на Ононском Курултае титул Чингисхана и объявивший себя прямым преемником хуннских, жужаньских и тюркских каганов. Эта систематизация получила названия «Их засаг хууль» или же «Великая Яса 1206 года», что переводится с монгольского языка (близкого тюркским наречиям VI века) как «Закон Великой Власти». Однако, с момента основания и существования Тюркского Эля (552-603 гг.), обычаи степняков были традиционно открыты к двум ветвям влияния - несторианской $/$ ортодоксальной (византийская ветвь) и буддистской (китайская ветвь). По сути, борьба цивилизационно шла между Китаем и Новым Римом, каждый из которых в культурном аспекте обладал возможностями «перетянуть одеяло на себя» и полностью поглотить Тюркский каганат - от сопок Маньчжурии до порогов Днепра. император Юстин II начал подавать отчетливые признаки заболевания шизофренией [9, с. 298]. Он «выл как собака», изображал различных зверей и птиц во время приема послов, смеялся и грустил не к месту, его умственные способности начали полностью угасать. Тюрки еще могли отнестись к этому факту как к норме тогдашнего общества, когда болезни и умалишения были, в общем то, обыденным состоянием позднеантичного и раннесредневекового общества. Вокруг свирепствовала «юстинианова чума», вдовы и вдовцы сходили с ума после уничтожения вражескими армиями их населенных пунктов, в этой больной среде находили своих фанатических сторонников различные сектанты маздакитского, несторианского, монофизитиского и даже буддистского толка. Всё это тюрки могли понять, тем более, что тщательное изучение древнетюркского фольклора приводит нас к мысли об исключительно толерантном отношении тюрок к психически нездоровым людям [17, с. 299-324]. Следовательно, культурные предпосылки для толерантности Муган-кагана к Юстину существовали серьезные.

Впрочем, тюрок очень беспокоила роль Августы Софии, жены Юстина, её исключительное влияние на Тиберия, с момента его фактического управления страной в 574 г. Болезнь императора и отстутствие адекватного управления Восточной Римской империей в 573-578 гг. (целых пять лет) [9, с. 299-309], борьба Тиберия в первый год со сторонниками Софии, её заточение, женитьба Тиберия и поражения на итальянском фронте от напуганных славяно-аварскими набегами лангобардов - весь этот перечень внутриполитических неудач Византии создавал неблагоприятное впечатление для потенциальных реципиентов христианской идентичности.

Бага-Ышбар-хан (581-587), вплоть до 582 г., пока на византийском троне находился Тиберий-Константин 


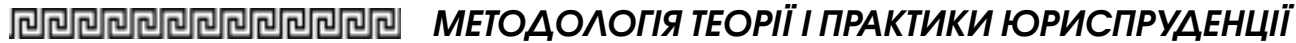

(578-582), активно искал основного союзника. Ему удалось заключить в 582 г. перемирие с персами и вернуть в действие договор о праве foedus на Волго-Днепровскую степь, полученный еще Муган-каганом в 567-568 гг. Таким образом, в начале 582 г. полностью прекратились боевые действия между западнотюркской ордой с одной стороны и причерноморскими федератами императора Тиберия с другой стороны [31, с. 67; 38, с. 305]. Этот шаг стал последней внешнеполитической игрой Тиберия. Вскоре он умер. На его место взошел бывший нотарий, а теперь зять Тиберия, генерал армии, дукс Месопотамии и Мидии, а также официально провозглашенный престолонаследник - Маврикий [9, с. 338-339].

Церемония коронации Маврикия состоялась в Соборе Святой Софии, перестроенном в 537 г. Юстинианом Великим. Константинопольский патриарх «венчал на царство Маврикия», объявив при этом завещание Тиберия о том, что Маврикий официально является «представителем династии Юстиниана». Действительно, с косвенной точки зрения, женившись в 583 г. на старшей дочери Тиберия, который сам формально пребывал в родстве с Юстином II и линией двоюродных племянников Юстиниана Великого, Маврикий мог претендовать на статус представителя Юстиниановой семьи $[9$, с. 340]. И, в этом контексте, он сумел развернуть достаточно эффективную агитационную кампанию еще перед смертью Тиберия, обещая всем гражданам и подданным Восточной Римской империи «достойную жизнь», уменьшение налогов, но, вместе с тем, и приумножение имперского величия «золотого века 527-565 гг.» [9, с. 338-342]. Напомним, что к моменту восшествия Маврикия на византийский престол, прошло всего лишь семнадцать лет после смерти Юстиниана Великого. Большинство чиновников и легатов, помогавших Юстиниану в создании Аварского каганата 558 г., в переговорах с Тюркским Элем 563-565 гг., в составлении мирного договора с Хосровом Ануширваном в 562 г., еще здравствовали. Не было в живых ни Юстиниана, ни Хосрова, но сформированная ими политическая повестка оставалась как никогда актуальной. Первейшим своим решением Маврикий должен был разрешить спорные вопросы тюркско-византийских отношений и «переучредить» совместный союз с алтайской ставкой кагана, направив его против Ормизда Тюркзаде (579-590).

Напомним: в 579-582 гг. Маврикий формально занимал должность магистра милитум Восточной Римской империи в азиатских провинциях [26, с. 16], а также являлся дуксом Месопотамии, Ассирии и Мидии. Он осуществил поход к побережью Каспийского моря, отрезал Дербент от Иранского нагорья и, успешными переговорами, создал угрозу Вавилону и Ктесифону со стороны гассанидских арабов. Провозглашение самого себя не просто преемником, но «родственником» Юстиниана Великого подействовало на широкие народные массы, которые, после кризиса в династической цепочке «Юстин-София-Тиберий» пытались найти какую-нибудь опору если не в политическом, то в каком-нибудь религиозном деятеле.

Отсюда растут корни особого роста роли и мощи (во времена Юстина II и Тиберия) несторианских и монофизитских проповедников в Сирии, Аравии и Египте, их проникновения в Малую Азию [9, с. 299-303], где они проповедовали близость апокалипсиса (конца света), неверность истолкования Евангелий ортодоксальными проимперскими патриархатами, часто даже агитировали за «воссоединение» азиатских провинций Нового Рима с «традиционным покровителем азиатов» - Сасанидским Ираном.

Подчеркнем: роль всевозможных еретических учений росла 
пропорционально падению внутреннего и внешнего (вспомним тюркский вопрос 576-582 гг.) авторитета верховной власти императора Восточной Римской империи. То, что он оставался «главной фигурой Ойкумены Христианского Мира» согласно нормам римского публичного права и ортодоксальной канонической юриспруденции, никак не коррелировало с общим восприятием его политических неудач. После Юстиниана Великого ни Юстин, ни Тиберий просто не могли править «хорошо» в народных глазах. На фоне Юстиниана, даже для тех многих аристократов, которые его ненавидели, и Юстин, и София, и Тиберий были слишком мелкими фигурами; они остались «личностями физическими» и не сумели по настоящему стать «личностями политическими». История, как известно, не прощает такого не только правителям, но и подвластным народам.

Маврикий короновался императором 13 августа 582 года. Тиберий-Константин (578-582) же, как известно, умер только 14 августа 582 г. Он самостоятельно принял решение передать империю под управление зятя за день до своей смерти, поскольку боялся гражданского неповиновения среди традиционно недовольных анатолийских землевладельцев-латифундистов. Считается, что Тиберий умер от чахотки, однако, вполне возможно, что его смерть была связана с чумой, названий для которой у византийских хронистов существует множество. В 581-583 гг. как раз был очередной виток так называемой «юстиниановой чумы», унесший жизни около 100 тыс. жителей империи. К тому времени, после первой вспышки на грани 530-540-х гг. «юстинианова чума» стала сезонным заболеванием и проявлялась почти каждый год, активно способствуя уменьшению населения в Малой Азии, Сирии и Египте. Войны с персами воспринимались людьми только как дополнительная напасть. Главной бедой
VI века, «Божьей Карой», конечно же, считалась «юстинианова чума».

Люди по всей империи радостно восприняли весть о том, что императором в Софийском Соборе провозглашен именно завоеватель персидской Мидии. Человек, командовавший в 574-582 гг. на персидском фронте и давший первую крупную победу в постоянных войнах с Ираном, считался достойным преемником великодержавных замыслов Юстиниана Великого. Люди жили насущными вопросами персидских вторжений и памятью об уничтожении населения Антиохии и Дары Хосровом Ануширваном, они хотели решения своих проблем. Вот почему Маврикий изначально не смог концентрировать внимание на тюркских или славяно-аварских проблемах. Его, в первую очередь [9, с. 342], должно было интересовать создание действенной имперской администрации в Мидии, Прикаспии, на землях Ассирии, неоднократно переходивших в прошлом из римских в персидские руки и наоборот.

Таким образом, в 582 г. Маврикий подтвердил перемирие Тиберия с западнотюркскими представителями БагаЫшбар-хана (581-587) и официально одобрил строительство тюрками крепости Тьмутаракань на Таманском полуострове. Именно в 582-583 гг. центр западнотюркской орды с главными багадурскими кочевьями смещается из контролируемой огузами астраханской приволжской степи на реку Кубань. В междуречье Кубани и Дона тюрки организовали свою ставку, понемногу создавая институты контроля над утригурами, аланами, сабирами и горными племенами грузин. Важно, что и Тиберий, и Маврикий в 582 г. фактически передали под власть западнотюркской орды треть грузинской территории Северного Кавказа, что, однако, не лишало грузин статуса федератов Восточной Римской империи. Впрочем, грузинское направление во времена Бага-Ышбар-хана

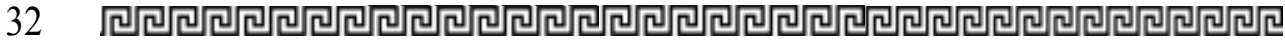




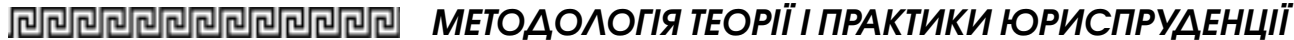

(581-587), Ормизда Тюркзаде (579-590) и Маврикия (582-602) однозначно ушло на третий план международной политики. Второстепенными являлись события, связанные с вялотекущей войной против лангобардов в Северной Италии, которую поневоле приходилось возглавлять не столько восточноримскому императору Маврикию, сколько Римскому Папе Пелагию II (579-590). На первый план для Византии вышла персо-мидийская операция и необходимость удерживать оккупированные территории [9, с. 342-349].

Стаття репрезентує спробу порівняльного аналізу ірано-візантійських та візантійсько-тюркських політичних відносин у період 579-584 років. Автор користується політологічним та історіографічним інструментарієм для висвітлення ключових юридичних проблем у системі міжнародних відносин другої половини VI століття нашої ери. Такими проблемами запропоновано вважати: 1) отримання та подальше використання «варварськими» племенами права foedus від візантійських (східноримських) монархів; 2) політичне функиіонування Великого Тюркського Елю (Тюркського каганату) на засадах полівасальної залежності від Сасанідського Ірану та Візантії, водночас; 3) утвердження авестійської правосвідомості в Персії. Відтак иим трьом найважливішим юридичним позиціям відповідають три етапи владних трансформацій, що відбулись в означений період. 1. У 579 році шахіншахом Iрану став Ормізд IV (579-590) - молодший син Хосрова Ануширвана. 2. У 581 році каганом Тюркського Елю став Бага-Ишбар-хан (581-587). У 582 році Східну Римську імперію очолив генерал вірменського походження Маврикій (582-602). Оскільки на період «n'ятирічної нестабільності» припадае три зміни влади у трьох найбільших політичних утвореннях Старого Світу, то запровадження иього терміну видається доречним. Крім того, трансформації верховної влади негайно призводили до зміни дипломатичних орієнтирів. Приклади: Персія в 579-580 роках відмовилась від курсу на примирення з Візантією, Тюркський каганат в 581 році знову почав ворогувати з Персією та зближуватись 3 Візантією, Східна Римська імперія в 582-584 роках намагалась відновити антиперсидський союз із тюрками. Врешті, ці рухи були невдалими $i$ не призвели до повної зміни геополітичної ситуації. Однак на фоні таких політичних «вагань» особливо вирізняються окремі юридичні практики та звичаї. Саме із ними, без відриву від фактологіï періоду, стаття знайомить читачів.

Ключові слова: Східна Римська імперія (Візантія), Великий Тюркський Ель (Тюркський каганат), Новоперсидське царство (Ераншахр), lex foedus, федерати, авестійська ідеологія, нехалкідонське християнство.

Melnyk V. "Five years of instability" period (579-584 ad): political and legal features of the Iranian-Byzantine and ByzantiumTurkic relations

The article represents an attempt at a comparative analysis of IranianByzantine and Byzantine-Turkic political relations in 579-584. The author uses political science and historiographical tools to highlight key legal issues in the international relations system of the second half of the VI century AD. Such problems are proposed to be considered: 1) obtaining and further use by the "barbarian" tribes of the byzantine lex foedus; 2) the political functioning of the Göktürk Khaganate based on vassal dependence on Sassanid Iran and Byzantium, at the same time; 3) the establishment of Avestan legal 
consciousness in Persia. Thus, these three most important legal positions correspond to the three stages of power transformations during this period. 1) In 579, Hormizd IV IV (579-590), the youngest son of Khosrow Anushirvan, became the šāhānšāh of Iran. 2) In 581, Ishbara Qaghan (581-587) became the Göktürk Khaganate's kagan. 3) In 582, the Eastern Roman Empire was headed by a general of Armenian descent, Maurice (582-602). Given the period of "five years of instability", there are three government changes in the three largest political entities in the old World. So, the introduction of this term seems appropriate. Besides, the transformation of the supreme power immediately led to a change in diplomatic guidelines. Examples: Persia in 579-580 abandoned the course of reconciliation with Byzantium, the Turkic Khaganate in 581 began to be at enmity with Persia again, the Eastern Roman Empire in 582-584 tried to restore the antiPersian alliance with the Turks. In the end, these movements were unsuccessful and did not lead to a complete change in the geopolitical situation. However, against the background of such political "fluctuations", certain legal practices and customs stand out. It is with them, without separation from the facts of the period, the article introduces readers.

Key words: Eastern Roman Empire (Byzantium), Göktürk Khaganate, Ērānšahr, lex foedus, foederati, Avestan ideology, non-Chalcedonian Christianity.

\section{Литература}

1. Мельник B.М. Кінець античності: як $і$ коли слов'яни вийшли на світову арену міжнародних відносин? Всесвіт. 2019. № 9-10-11-12. С. 203-208.

2. Дмитриев В.А. Борьба Римской (Византийской) империи и Сасанидского Ирана за преобладание в Передней Азии (III-VII вв.). Псков : ПГПУ, 2008. 148 c.

3. Мишин Д.Е. Хосров I Ануширван (531-579), его эпоха и его жизнеописа- ние и поучение в истории Мискавейха. Москва : Институт востоковедения PAH, 2014. 696 c.

4. Фирдоуси. Шахнаме. T. VI. (Om начала царствования Йездгерда, сына Бахрама Гура до кониа книги). Пер. с фарси Ц. Б. Бану-Лахути и В. Г. Берзнева, коммент. Л. Лахути. Москва, 1989.

5. Wood Philip. The Christian Reception of the Xwadāy-Nāmag: Hormizd IV, Khusrau II and their successors. Journal of the Royal Asiatic Society. 2016. Vol. 26. Issue 3. Pp. 407-422.

6. John Bishop of Ephesus, ca. 507-586. The Third Part of the Ecclesiastical History. Oxford: University Press, 1853. XIII+418 pp.

7. Феофилакт Симокатта. История. Вступ. ст. Н. В. Пигулевской. Пер. С.П. Кондратьева. Москва : Арктос; Вика-пресс, 1996. 272 c.

8. Давыдов Клим. Геополитическая история Азербайджана исторического и новосозданного. Москва : «Перо», 2020. $396 \mathrm{c}$.

9. Кулаковский Ю.А. История Византии. Т. II. 518-602 ге. Санкт-Петербург : Алетейя, 1996. $400 \mathrm{c}$.

10.Беда P.A. «Стратиг Тиберий»: $\kappa$ вопросу о военном опыте императора Тиберия II. Известия Алтайского государственного университета. 2013. № 4-2(80). С. 31-33.

11. Мельник B.М. Теорія $і$ практика маздакізму: соціально-політичний аспект. Вісник Львівського університету. Серія філософсько-політологічні cmydiï. 2020. Bun. 30. C. 183-190.

12. Payne Richard. Cosmology and the expansion of the Iranian empire, 502-628 C.E. Past \& Present. 2013. Vol. CCXX. Issue 1. Pp. 3-33.

13. Диль Ш. Юстиниан и византийская иивилизация в VI веке. Санкт-Петербург : Типография Альтшулера, 1908. $X X X I V+687 c$

14. Çağlayan Yegane. V-VII. Yüzyıllarda Uluslararasi Ticarette Bizans ve Sasani Rekabeti. Anemon Mus Alparslan bniversitesi Sosyal Bilimler Dergisi. 2020. Vol. 8. Issue 2. Pp. 645-653.

15. Пигулевская Н.В. Византийская дипломатия и торговля шелком. Византийский временник. 1947. T. 1 (XXVI). C. 184-214.

16. Мамбеталиев А.Э. След Христа на шелковом nymu. Bishkek : Janyzak Print, 2013. $53 \mathrm{c}$. 


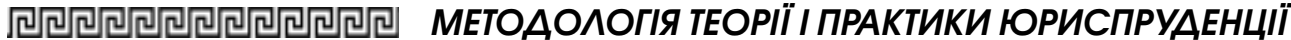

17. Гумилев Л.Н. В поисках вымышленного иарства. Санкт-Петербург : Азбука-классика, 2014. 480 c.

18. Мельник В.М. Юридическая правосубъектность Тюркского каганата $(552-568 \quad$ гг.): аспект. Юридичний вісник. Юридический вестник. Law Herald. Oдеса: Haцiональний університет «Одеська юридична академія», 2020. № 4. С. 139-155.

19. Гумилев Л.Н. Древние тюрки. Москва : Кльшников и Комаров и Ко., 1993. 536 c.

20. Pourshariati Parvaneh. Decline and Fall of the Sasanian Empire. The SasanianParthian Confederacy and the Arab Conquest of Iran. London and New York: I.B. Tauris \& Co Ltd, 2008. 553 pp.

21. Грацианский М.В. Император Юстиниан Великий и наследие Халкидонского Собора. Москва: Издательство Московского университета, 2016. 391 c.

22. Мельник B.М. Церковно-политический сепаратизм в пределах юго-восточной Византии: публично-правовой контекст (553-564 годы). Актуальні проблеми держави і права. 2020. Випуск 87. C. 113-119.

23. Кьчинов Е.И. Сирийское несторианство в Китае и Центральной Азии. Палестинский сборник. Bып. 26 (89). Филология и история. Ленинград : «Наука», 1978. C. 76-85.

24. Бартольд В.В. История культурной жизни Туркестана. Ленинград : Изд-во АН СССР, 1927. 256 с.

25. Аюбов А.Р. Особенности эволюиии согдо-тюркских взаимоотношений в раннем средневековье. Вестник Таджикского государственного университета права, бизнеса и политики. Серия гуманитарHolx наук. 2017. № 1(70). C. 27-35.

26. Беда P.A. Военная знать Ранней Византии в послеюстиниановскую эпоху (565-641 ге.). Автореферат диссертации на соискание учёной степени кандидата исторических наук. Белгород, 2015. 23 c.

27. Лаврів П.І. Історія Південно-Східної України. Київ : Видавництво ім. Олени Теліги, 1996. 192 с.

28. Менандр Византиеи. История. Византийские историки: Дексипп, Эвнапий, Олимпиодор, Малх, Петр Магистр, Менандр, Кандид Исавр, Ноннос и Феофан Византиец / Перевод Г.С. Дестуниса. Рязань: Александрия. 2003. С. 229-335.
29. Prokopios. The Wars of Justinian. Trans. by $H$. B. Dewing, revised by A. Kaldellis. Hackett Publishing Company, Inc., 2014. 642 p.

30. Procope de Cüsarùe. Constructions de Justinien Ier. Introduction, traduction, commentaire, cartes et index par Denis Roques, publication posthume par E. Amato et J. Schamp. Alessandria : Edizioni dell'Orso, 2011. XII+469 pp.

31. Болгов Н. Межау империей и варварами: финал античности на Боспоре Киммерийском. Україна в Центрально-Східній Eвропі. 2004. № 4. С. 39 -76.

32. Венелин Юрий. Древние и нынешние болгаре в политическом, народописном, историческом и религиозном их отношении к россиянам. Москва : Университетская типография, 1841. 114 c.

33. Мельник B.М., Шишкина Е.В. Ранняя этническая история южных славян. Запорожье : Запорожский государственный педагогический институт, 1978. $98 \mathrm{c}$

34. Собестианский И.М. Учения о национальных особенностях характера и юридического быта древних славян : историко-критическое исследование. Харьков, 1892. ХII+340 c.

35. Мастыкова А.В. Костюм населения Сирмия в эпоху Великого переселения народов. Материаль по археологии, истории и этнографии Таврии. Выпуск XXIV. 2019. C. 94-108.

36. Wasilewski T. Historia Butgarii. Wroctaw: Ossolineum, 1988. $163 \mathrm{~s}$.

37. Дайм Фалько. История и археология авар. Материаль по археологии, истории и этнографии Таврии. 2002. Bып. IX. C. $273-384$

38. Айбабин А.И., Хайрединова Э.А. Крымские готы страны Дори (середина III-VII вв.). Симферополь : Антиква, 2017. $368 \mathrm{c}$.

39. Мельник В.М. Борьба Византии за право владения Италией: историко-юридическая характеристика войнь 541-552 ге. Анналы юридической истории. 2019. Том 3. Выпуск 1-2. C. 65-104.

40. Поповић B. Sirmium. Град царева и мученика. Сремска Митровица: Благо Сирмиіума, 2003. 364 c.

41. Moravcsik Gy. Byzantinoturcica. Bd. II. Berlin, 1958. 326 s.

42. Артамонов М.И. История хазар. Ленинград : Издательство Госудаственного Эрмитажа, 1962. 523 с. 